\title{
Systemic RNAi mediated gene silencing in the anhydrobiotic
} nematode Panagrolaimus superbus

\author{
Adam J Shannon ${ }^{1}$, Trevor Tyson ${ }^{1}$, Ilona Dix ${ }^{1}$, Jacqueline Boyd ${ }^{1,2}$ and \\ Ann M Burnell*1
}

Address: ${ }^{1}$ Biology Department, National University of Ireland, Maynooth, Co. Kildare, Ireland and ${ }^{2}$ School of Animal, Rural and Environmental Sciences, Nottingham Trent University, Nottingham Rd., Southwell, NG25 0QF, UK

Email: Adam J Shannon - adam.j.shannon@nuim.ie; Trevor Tyson - trevor.tyson@nuim.ie; Ilona Dix - ilona.dix@nuim.ie; Jacqueline Boyd - jacqueline.boyd@nty.ac.uk; Ann M Burnell* - ann.burnell@nuim.ie

* Corresponding author

Published: 19 June 2008

BMC Molecular Biology 2008, 9:58 doi:10.1 186/147/-2199-9-58

This article is available from: http://www.biomedcentral.com/147I-2199/9/58

(c) 2008 Shannon et al; licensee BioMed Central Ltd.

This is an Open Access article distributed under the terms of the Creative Commons Attribution License (http://creativecommons.org/licenses/by/2.0), which permits unrestricted use, distribution, and reproduction in any medium, provided the original work is properly cited.
Received: 24 February 2008

Accepted: 19 June 2008

\begin{abstract}
Background: Gene silencing by RNA interference (RNAi) is a powerful tool for functional genomics. Although RNAi was first described in Caenorhabditis elegans, several nematode species are unable to mount an RNAi response when exposed to exogenous double stranded RNA (dsRNA). These include the satellite model organisms Pristionchus pacificus and Oscheius tipulae. Available data also suggest that the RNAi pathway targeting exogenous dsRNA may not be fully functional in some animal parasitic nematodes. The genus Panagrolaimus contains bacterial feeding nematodes which occupy a diversity of niches ranging from polar, temperate and semi-arid soils to terrestrial mosses. Thus many Panagrolaimus species are adapted to tolerate freezing and desiccation and are excellent systems to study the molecular basis of environmental stress tolerance. We investigated whether Panagrolaimus is susceptible to RNAi to determine whether this nematode could be used in large scale RNAi studies in functional genomics.
\end{abstract}

Results: We studied two species: Panagrolaimus sp. PSII59 and Panagrolaimus superbus. Both nematode species displayed embryonic lethal RNAi phenotypes following ingestion of Escherichia coli expressing dsRNA for the $C$. elegans embryonic lethal genes Ce-Imn-I and Ce-ran-4. Embryonic lethal RNAi phenotypes were also obtained in both species upon ingestion of dsRNA for the Panagrolaimus genes ef $I b$ and $r p s-2$. Single nematode RT-PCR showed that a significant reduction in mRNA transcript levels occurred for the target ef $l b$ and rps-2 genes in RNAi treated Panagrolaimus sp. II 59 nematodes. Visible RNAi phenotypes were also observed when $P$. superbus was exposed to dsRNA for structural genes encoding contractile proteins. All RNAi phenotypes were highly penetrant, particularly in $P$. superbus.

Conclusion: This demonstration that Panagrolaimus is amenable to RNAi by feeding will allow the development of high throughput methods of RNAi screening for $P$. superbus. This greatly enhances the utility of this nematode as a model system for the study of the molecular biology of anhydrobiosis and cryobiosis and as a possible satellite model nematode for comparative and functional genomics. Our data also identify another nematode infraorder which is amenable to RNAi and provide additional information on the diversity of RNAi phenotypes in nematodes. 


\section{Background}

RNA interference (RNAi) was first described in the nematode Caenorhabditis elegans $[1,2]$, when it was found that the injection of double-stranded RNA (dsRNA) into a hermaphrodite worm resulted in the degradation of endogenous mRNA corresponding in sequence to the injected dsRNA. This resulted in a loss of function phenotype for the target gene. Potent RNAi effects can also be achieved in C. elegans by soaking the nematodes in a dsRNA solution [3] or by feeding the nematodes on bacteria engineered to express dsRNA of the target gene [4]. The potential for RNAi by feeding to be used in a large scale manner for functional genomics was demonstrated by the construction of a feeding library corresponding to $86 \%$ of the 19,000 predicted genes in C. elegans [5]. This library has already been screened for genes involved in a wide range of biological processes including development $[6,7]$, ageing [8-10], cell biology $[11,12]$ and neurobiology [13].

RNAi effects have now been detected in all eukaryote groups; phylogenetic analyses suggest that the main components of the RNAi machinery can be traced back to the last common ancestor of the eukaryotes [14]. Gene silencing by RNAi is the outcome of a complex co-ordinated process. Many of the essential proteins involved in this process have been identified. RNAi is initiated by the cleavage of exogenous dsRNA into short interfering RNAs (siRNAs) by a dsRNA-specific RNAse enzyme Dicer [15]. These double-stranded 21 nucleotide siRNAs interact with, and activate, a multiprotein RNA-induced silencing complex (RISC) and the activated RISC then recognises and cleaves RNA molecules homologous to the interfering siRNA $[16,17]$. Gene silencing via RNAi can also be triggered by endogenous double stranded micro RNAs (miRNAs) which regulate gene expression at the posttranscriptional level in metazoans [18] and plants [19]. RNAi-related mechanisms are also involved in heterochromatin formation [20,21].

Although the core features of the RNAi response are conserved among eukaryotes, several taxon-specific variations occur. Taxa differ in their ability to take up dsRNA, to transmit siRNA systemically to other tissues and in the magnitude and duration of the RNAi response. While various cell types can efficiently take up dsRNA in Drosophila melanogaster [22], the response is cell autonomous and the flies are unable to produce a systemic response to the localized introduction of dsRNA [23]. Naturally occurring systemic transmission of siRNAs also appears to be absent from vertebrates. Other organisms including C. elegans [1], the insect parasitic nematode Heterorhabditis bacteriophora [24], the planarian worm Schmidtea mediterranea [25], the coelenterate Hydra [26], insect species including a grasshopper [27] and cockroach [28] and several plant species [29-32] have the ability to generate a systemic RNAi response. In C. elegans two genes sid-1 and sid-2 are required for the uptake of dsRNA from the intestine (sid = systemic RNAi-deficient) [33,34]. SID-1 is a multispan transmembrane protein which appears to function as a channel for the diffusion of dsRNA [33,35], and expression of nematode SID-1 in Drosophila cells which lack a sid-1 homolog resulted in the rapid import of dsRNA into the cells [35]. Although sid-2 mutants fail to show a systemic RNAi response to ingested dsDNA, the injection of dsRNA into the pseudocoel of these mutants generated a strong systemic RNAi response in the treated worms [34]. SID-2 encodes a single-pass transmembrane protein which is expressed in the membranes of the intestine lumen and although its mode of action has yet to be determined, SID-2 is an essential requirement for environmental RNAi in C. elegans [34].

Because of the complexity of the dsRNAi pathway, the loss of a specific RNAi component protein or the occurrence of mutations may lead to the lack of a systemic RNAi response. Exogenous dsRNAi function has been lost from specific lineages such as Saccharomyces cerevisiae [14] and Trypanosoma cruzi [36]. Lack of both a systemic and a cellautonomous RNAi response to injected dsRNA was also observed in the free living nematodes Oscheius tipulae $[37,38]$ and Pristionchus pacificus $[39,40]$. Testing of strains within the Caenorhabditis clade for susceptibility to RNAi by different delivery methods indicated that most strains are capable of a systemic RNAi response if dsRNA is delivered via microinjection, however six of the eight Caenorhabditis species tested, including C. briggsae, were resistant to dsRNAi via soaking or feeding $[34,41]$. When SID-2 from C. elegans was expressed in C. briggsae it conferred sensitivity to RNAi by soaking [34]. A naturally occurring strain of C. elegans from Hawaii was found to be resistant to RNAi by feeding or injection of germlineexpressed genes and this defect was the result of mutations in the Argonaute gene $p p w-1$ [42]. The minimum defining feature of a RISC complex is that it contains one Argonaute family member and a small-RNA guide strand [43]. The Argonaute gene family contains 20 members in C. elegans [44], which suggests that several distinct RISC complexes may be formed in this organism. Resistance or partial resistance to RNAi has also been demonstrated in animal parasitic nematode species such as Haemonchus contortus [45] and Ostertagia ostertagi [46]. This resistance to RNAi may be due to difficulties in developing suitable in vitro culture conditions and delivery methods for these parasites, but the available data suggest that the RNAi pathway may not be fully functional in some animal parasitic nematodes [47]. By contrast, several plant parasitic nematode species are susceptible to RNAi, including the nematodes Heterodera glycines and Globodera pallida [48] and Meloidogyne incognita [49]. Viney and Thompson [50] 
propose that the limited success of RNAi in animal parasitic nematodes to date might be circumvented if, instead of the soaking protocols currently in use, the dsRNA were delivered to the worms' pseudocoel. Alternatively it may be necessary to genetically engineer animal parasitic nematodes to express the sid-1 and sid-2 genes from C. elegans [50].

Native Drosophila S2 cells lack a SID-1 homolog, however these cells become competent to take up dsRNA when exposed to brief serum starvation in the presence of dsRNA, followed by incubation in medium containing serum [22,51]. Systemic RNAi effects in C. elegans body wall muscles are also enhanced by starvation [33]. Observations in C. elegans and Drosophila suggest that environmental or physiological signals may be important in the uptake and spread of dsRNA. Using an RNAi approach Saleh et al. [52] have shown that dsRNA is taken up in serum starved Drosophila S2 cells by receptor mediated endocytosis and these authors demonstrated that a functional intracellular vesicle transport system is also required for systemic RNAi in C. elegans. It has been hypothesized that an RNAi response to exogenous dsRNA evolved as a defence against infectious transposons and viruses $[53,54]$. Many viruses encode viral suppressors of RNA silencing (VSRs) to counteract the hosts' defence against viral encoded dsRNAs [55]. VSRs target several of the key steps in the RNA silencing pathway and VSRs encoded by viruses of different families often share no homology at the primary amino acid sequence level [55]. Pharmacological evidence suggests that in serum starved Drosophila S2 cells dsRNA uptake is mediated by pattern recognition receptors of the scavenger-receptor family [52], a family of receptors with roles in the innate immune response [56]. The ability to mount a systemic RNAi response to ingested dsRNA is absent in many Caenorhabditis species and it is also poorly developed in animal parasitic nematodes, and both systemic and cell autonomous RNAi are absent in the nematodes $P$. pacificus and $O$. tipulae. In contrast C. elegans, H. bacteriophora and several species of plant parasitic nematodes are susceptible to RNAi from environmentally supplied dsRNA. This phenotypic variability among nematodes may result from differing niche-specific selective pressures affecting environmental RNAi and the innate immune response.

We have previously shown that the free living bacterial feeding nematode Panagrolaimus superbus is a suitable model for studies on the molecular basis of anhydrobiosis because of its remarkable ability to survive extreme desiccation [57]. As a bacterial feeder, Panagrolaimus can be readily cultured in the laboratory with $E$. coli as a food source, using methods developed for C. elegans [58]. We therefore investigated whether Panagrolaimus is susceptible to RNAi by feeding. Our results show that potent and specific RNAi effects can be achieved in Panagrolaimus by feeding it on E. coli expressing dsRNA for genes with essential conserved functions. This demonstration that Panagrolaimus is amenable to RNAi by feeding will allow the development of high throughput methods of RNAi screening for P. superbus and further enhance the utility of this nematode as a model system for the study of the molecular biology of anhydrobiosis, and as a possible satellite model nematode for comparative and functional genomics.

\section{Results and Discussion}

Panagrolaimus fed with E. coli expressing dsRNA for C. elegans embryonic lethal genes give rise to progeny with highly penetrant embryonic lethal phenotypes

We tested two species of Panagrolaimus for RNAi effects using E. coli clones from a C. elegans feeding library [59]. The selected clones contained inserts from the genes $\mathrm{Ce}$ Imn-1 (DY3.2) and Ce-ran-4 (R05D11.3). The functions of these genes are conserved among eukaryotes and they yield severe embryonic lethal RNAi phenotypes in C. elegans [59]. The C. elegans genome contains a single lamin gene, lmn-1 which encodes a nuclear lamin protein [60]. Previous RNAi studies have shown that C. elegans $l m n-1$ (RNAi) embryos have defects in chromatin organization, cell cycle progression and chromosome segregation [60] and that embryogenesis is halted before the embryo is enclosed by epidermal tissue [6]. The Ce-lmn-1 (RNAi) Panagrolaimus embryos show similar defects to those described for $C$. elegans and the terminal arrest phenotype is similar in both nematode genera (Figure 1A, 1D, 1G). Ce-ran-4 encodes an ortholog of nuclear transport factor 2 [61] which is responsible for importing the Ras-related nuclear protein RanGDP into the nucleus [62]. Ran is an essential component in the transport of many proteins and nucleic acids between the nucleus and the cytoplasm [63]. RNAi of ran-4 in C. elegans resulted in an embryonic lethal phenotype in which the embryos arrested as a multicellular mass (<200 cells) and the nuclear membranes were indistinct $[6,61]$. The terminal arrest phenotypes of Ce-ran-4 (RNAi) embryos in Panagrolaimus were also similar to those of C. elegans (Figure 1B, 1E, 1H). Although embryonic lethal RNAi phenotypes were observed for both species of Panagrolaimus, the RNAi effect showed greater penetrance in $P$. superbus than in Panagrolaimus sp. 1159 (Figure 2). From Figure 2 it can also be seen that the penetrance of the heterologous RNAi effect observed in $P$. superbus for both dsRNA constructs was comparable to penetrance of the RNAi phenotypes observed in C. elegans which had been treated with homologous dsRNA constructs. All three species tested (C. elegans, Panagrolaimus sp. PS1159 and P. superbus) showed significant differences in the percentage dead embryos between the experimental and control populations for both target genes tested (Two sample T-Test, $\mathrm{P}=0.00)$. 

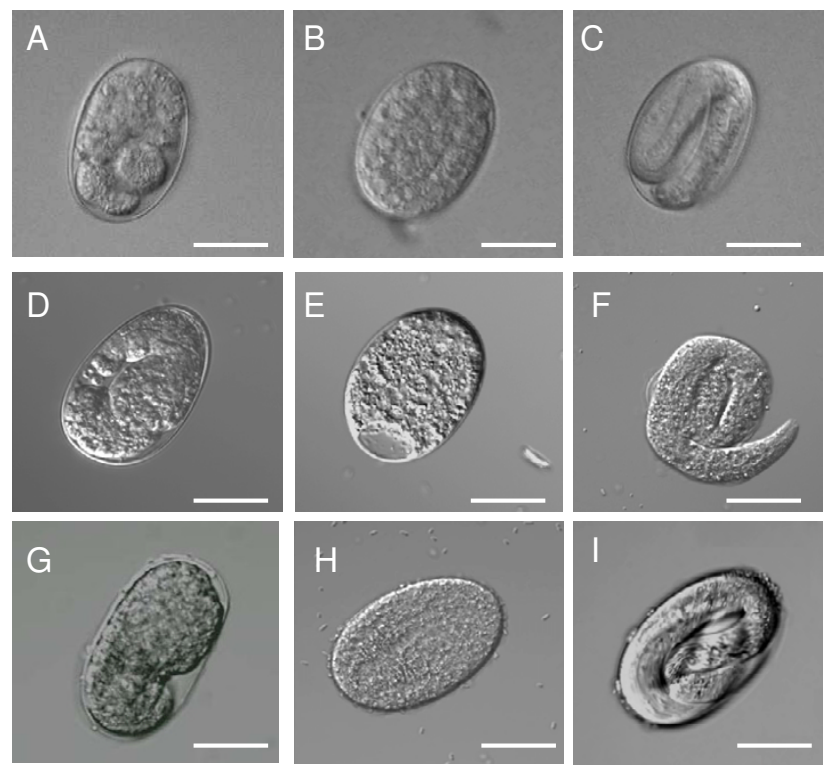

Figure I

The RNAi phenotypes obtained among the progeny of Panagrolaimus females fed on $E$. coli clones expressing dsRNA for the Caenorhabaditis elegans for the embryonic lethal genes Ce-Imn-I and Ce-ran-4. (A) Embryo from a $P$. superbus female fed on Ce-Imn-I; (B) Embryo from a $P$. superbus female fed on Ce-ran-4; (C) Control embryo from $P$. superbus fed on $E$. coli containing the empty L4440 plasmid vector; (D) Embryo from a Panagrolaimus sp. PSI I 59 female fed on Ce-Imn-I; (E) Embryo from a Panagrolaimus sp. PSI 159 female fed on Ce-ran-4; (F) Control embryo from Panagrolaimus sp. PSI I 59 fed on E. coli containing the empty L4440 plasmid vector; (G) Embryo from a $C$. elegans female fed on Ce-Imn- $I ;(H)$ Embryo from a $C$. elegans female fed on Ce-ran-4; (I) Control embryo from C. elegans fed on E. coli containing the empty L4440 plasmid vector. The scale bar represents $30 \mu \mathrm{M}$.

\section{Embryonic lethal RNAi phenotypes obtained by feeding Panagrolaimus with E. coli expressing dsRNA for Panagrolaimus genes}

E. coli feeding strains were constructed using sequences for two genes from Panagrolaimus sp. PS1159 whose orthologs have embryonic lethal RNAi phenotypes in $C$. elegans. These were the elongation factor 1-beta (ef1b) gene and the ribosomal protein small subunit S2 (rps-2) gene. The Ce-rps-2 gene demonstrated both a sterile maternal RNAi phenotype [64] and an embryonic lethal RNAi phenotype in C. elegans [65]. The Panagrolaimus rps-2 gene also yielded an embryonic lethal RNAi phenotype in both Panagrolaimus species tested (Figure 3A), with a significant difference in percentage dead embryos between the experimental and control populations in both cases (Two sample T-Test, $\mathrm{P}=0.00)$. Here also the heterologous RNAi effect in $P$. superbus ( $80 \%$ embryonic lethality) was
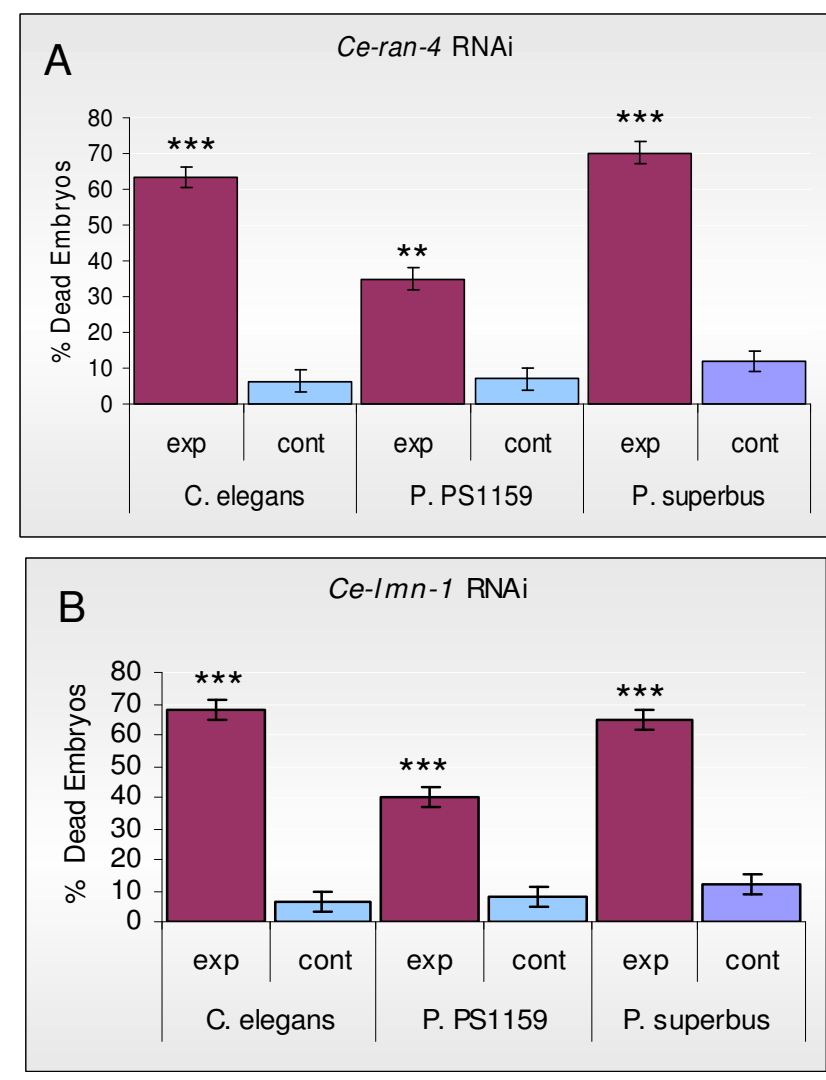

Figure 2

The penetrance of the dsRNAi embryonic lethal phenotypes observed among the progeny of $C$. elegans, $P$. superbus and Panagrolaimus sp. PSI I 59 following ingestion of $E$. coli expressing dsRNA for the embryonic lethal genes Ce-Imn-I and Ce-ran-4. (A) The percentage of embryonic lethal RNAi phenotypes observed in progeny of nematodes exposed to Ce-ran-4; (B) The percentage of embryonic lethal RNAi phenotypes observed in progeny of nematodes exposed to Ce-Imn-I. For both genes tested the control nematodes were fed on $E$. coli containing the empty L4440 plasmid vector. Data are presented as the mean and standard error of the mean of a minimum of 5 biological replicates, each replicate count containing a minimum of 50 embryos. $* * * P<0.001$; $* * P<0.01$ as compared to controls using a 2-tailed T test.

stronger than the homologous RNAi effect in Panagrolaimus sp. PS1159 (38\% embryonic lethality). The average number of eggs laid per female nematode was compared for the control and RNAi treated Panagrolaimus populations and a Two sample T-Test $(\mathrm{p}=0.62)$ did not reveal any significant difference in fecundity between the populations. The dsRNAi embryonic lethal phenotype for the Panagrolaimus sp. PS1159 ef1b gene also showed a stronger heterologous RNAi effect in P. superbus (53\% embryonic lethality) than the homologous RNAi effect in Panagrolaimus sp. PS1159 (39\% embryonic lethality), 

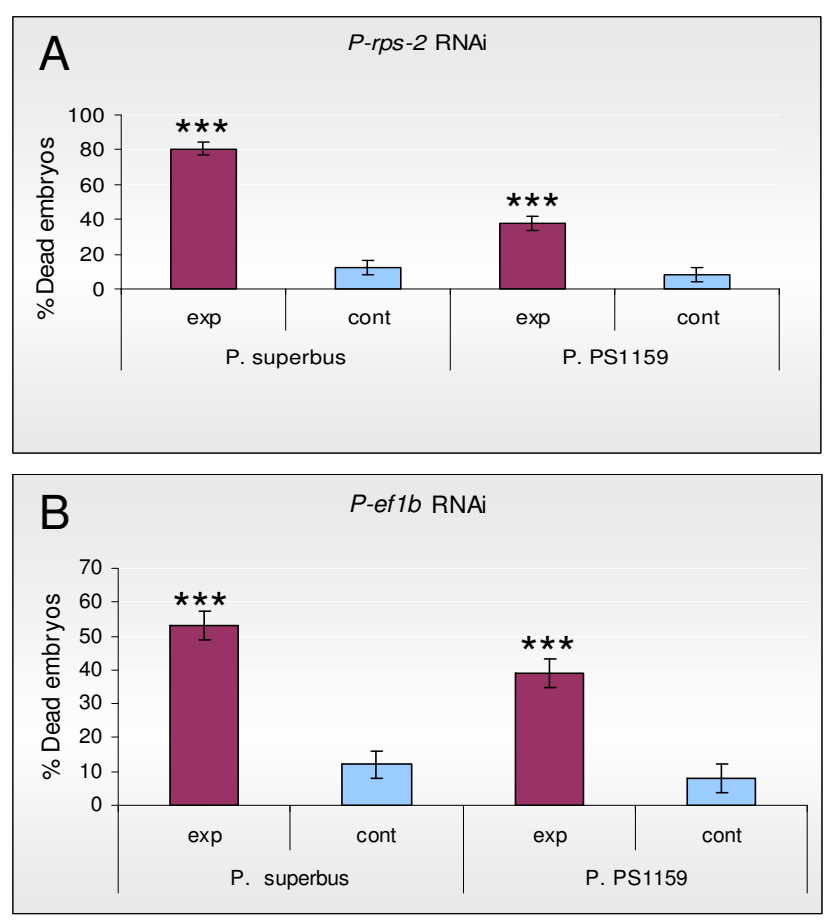

Figure 3

The percentage of embryonic lethal RNAi phenotypes obtained by feeding $P$. superbus and Panagrolaimus sp. PS I I 59 on E. coli feeding clones expressing dsRNA for the ef $l b$ and rps-2 genes from Panagrolaimus sp. PSI I 59. (A) The percentage of embryonic lethal progeny observed among the progeny of female nematodes exposed to dsRNA for P-rps-2; (B) The percentage of embryonic lethal progeny observed in nematodes exposed to dsRNA for $P$-efl $b$. For both genes tested the control nematodes were fed on $E$. coli containing the empty $L 4440$ plasmid vector. Data are presented as the mean and standard error of the mean of a minimum of 5 biological replicates, each replicate containing a minimum of 20 embryos $* * * p<0.001$; $* * P$ $<0.0$ l as compared to controls using a 2-tailed $\mathrm{T}$ test.

however there was a significant difference in the percentage of dead embryos between the experimental and control populations in both nematode species (Two sample T-Test, $\mathrm{P}=0.00$ ).

\section{Exposure of Panagrolaimus sp. PSII59 to homologous dsRNA by feeding results in a reduction of $m R N A$ transcript levels for the target genes}

Single nematode RT-PCR (Figure 4) showed that a reduction in mRNA transcript levels occurred for the target genes in the RNAi treated Panagrolaimus sp. PS1159 nematodes. For the ef $1 b$ gene the reduction in transcript level was $30 \%$ that of the controls while for the rps-2 gene the mRNA transcript levels were reduced to $55 \%$ of the controls (Figure 4C, D). There was no significant difference between the treated and control worms in the mRNA transcript levels for the D3 segment of the nuclear large subunit rRNA gene which was used as an internal control. This indicates that the dsRNAi effect in Panagrolaimus is specific for the targeted genes.

Exposing Panagrolaimus superbus to homologous dsRNA for genes encoding contractile proteins results in potent and highly penetrant locomotor and growth defects

E. coli feeding strains were constructed for two genes from Panagrolaimus suprbus whose C. elegans orthologs encode contractile proteins. These genes were Psu-ifb-1 and Psuact-2. Each of these genes has multiple RNAi phenotypes in C. elegans. The Ce-ifb-1 gene encodes two isoforms of a cytoplasmic intermediate filament protein that are expressed in the hypodermal cells of C. elegans, where they form attachment structures which connect the muscles to the cuticle [66]. These attachment structures transmit the contractile forces generated by the body muscles across the hypodermis to the cuticle. In C. elegans both IFB-1 isoforms have roles in epidermal morphogenesis and muscle attachment [67]. C. elegans larvae exposed to ifb-1 RNAi by feeding displayed a paralysis phenotype in which the hypodermis becomes detached from the cuticle [68]. Exposure of $P$. superbus L1 larvae to Psu-ifb-1 dsRNA by feeding resulted in a larval arrest and paralysis phenotype (Figure 5A). The phenotype was highly penetrant and the treated larvae were severely paralysed. Microscopic observations revealed waves or ripples of muscle contraction moving from the anterior to the posterior of the immobile worms, indicating that the contractile forces generated by the muscles were not being transmitted to the cuticle.

The C. elegans genome encodes five highly conserved actin genes. ACT-1, -2, -3 and -4 all share $99 \%$ amino acid identity, while ACT-5, the most divergent, shares $93 \%$ identity with the other actin isoforms [69]. The act $-1,-2,-3$ and -4 genes function primarily in muscle and myofilament containing cells in C. elegans $[69,70]$, while act-5 expression is restricted to cells which contain microvilli [71]. A variety of mutant and RNAi phenotypes have been associated with impared actin gene function in $C$. elegans, including defects in embryonic cell division [72], defects in muscle contractile function [73] including pharyngeal function [74], and growth defects [71]. P. superbus larvae grown on E. coli expressing Psu-act-2 dsRNA displayed severe larval lethal, larval arrest, and paralysed phenotypes (Figure 5B). The treated larvae were unable to grow beyond the first or second larval stages. The worms were immobile, although pharyngeal function appeared to be retained.

\section{Panagrolaimus: a potential satellite model nematode for functional genomics}

Comparative studies show that extensive genetic diversity occurs within the Phylum Nematoda [75,76]. Conse- 


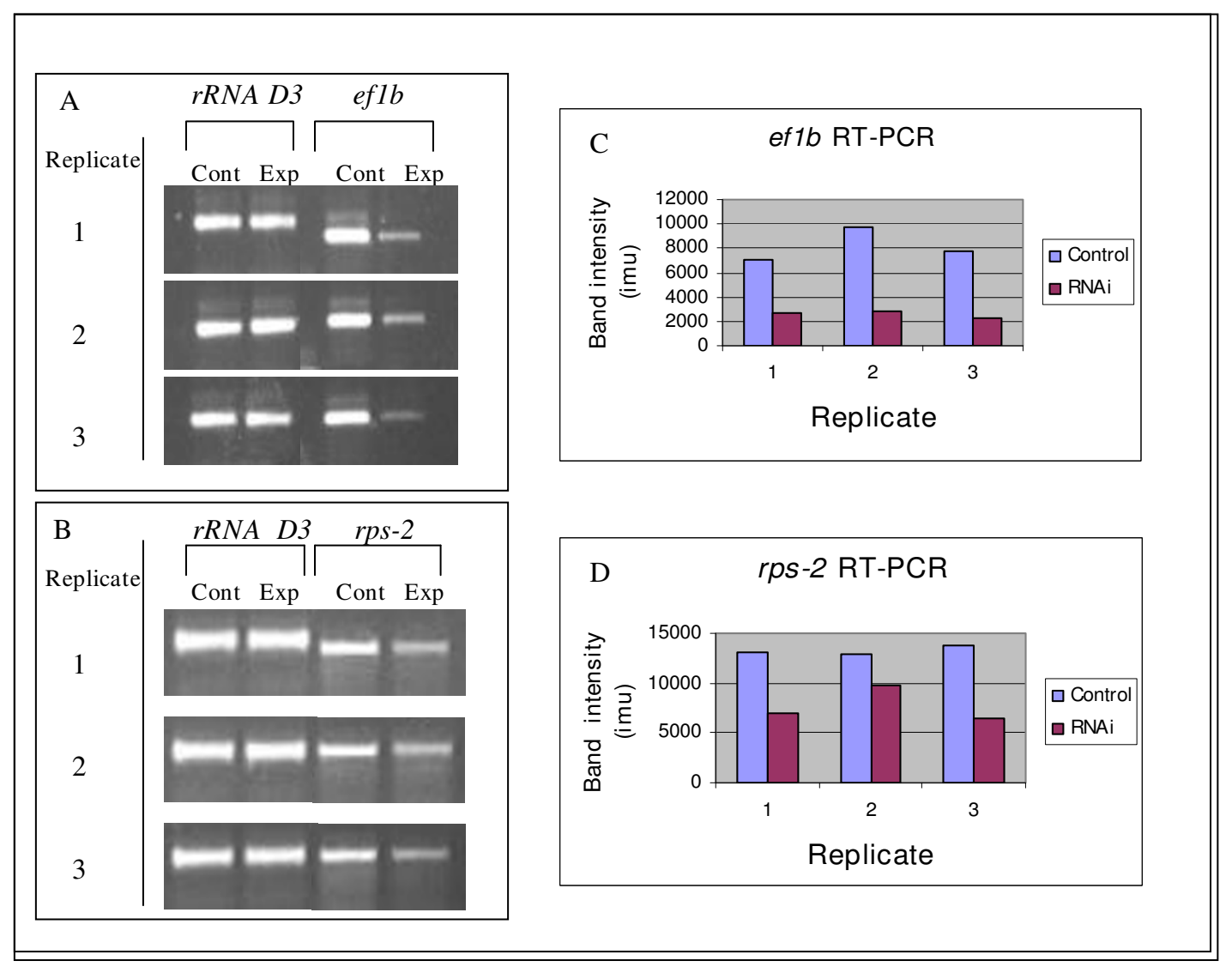

Figure 4

Single nematode RT-PCR to assess transcript levels for the $P$-efl $b$ and $P$-rps-2 genes in control and RNAi treated Panagrolaimus sp. PSI I 59 nematodes. RNA was isolated from individual nematodes whose progeny showed a positive RNAi phenotype and from individual control nematodes fed on $E$. coli containing the empty L4440 plasmid vector. Transcript levels were determined by RT-PCR for the target gene and for the rRNA D3 gene (which served as an internal control). (A) Transcript levels for the P-efIb and rRNA D3 genes in individual Panagrolaimus sp. PSI I59 adult females fed on E. coli expressing $P$-efl b dsRNA (each of the three replicates corresponds to a separate nematode); (B) Transcript levels for the $P$-rps2 and $r R N A D 3$ genes in individual Panagrolaimus sp. PSI 159 females fed on $E$. coli expressing P-rps-2 dsRNA (each of the three replicates corresponds to a separate nematode); (C, D) Quantification of the RT-PCR products for the $P$-efl $b$ and $P$-rps- 2 genes in control and RNAi treated Panagrolaimus sp. PSI I 59 nematodes. The band intensities are given in ImageQuant ${ }^{T M}$ machine units (imu).

quently it is not always possible to extrapolate from the model nematode C. elegans to other members of the Phylum Nematoda; studies in additional representative nematode species are often necessary. Several additional species of plant and animal parasitic nematodes have been selected as model organisms. Comparative studies are also carried out on other species in the Caenorhabditis clade $[76,77]$ and on the free-living bacterial feeding nematodes Oeschius tipulae [38,78] and Pristionchus pacificus $[40,79]$. Neither O. tipulae nor P. pacificus (both members of the suborder Rhabditina) display gene silencing in response to exogenous dsRNA. However injection of antisense morpholino DNA oligonucleotides into both of these satellite models results in a partial inactivation of the corresponding gene product [37] or in phenotypes with low penetrance [39]. Morpholino antisense oligonucleotides block mRNA translation when complementary to the 5' untranslated region of the target gene or to the first 25 bases downstream of the start codon, and they achieve their effect by preventing ribosomal binding [80]. The use of morpholinos presents difficulties for highthroughput gene knockout experiments because of the need for specific sequence information at the 5 ' end of the gene, the requirement for a means of delivery of the oligonucleotides to the target cells, and the lack of a systemic response. 

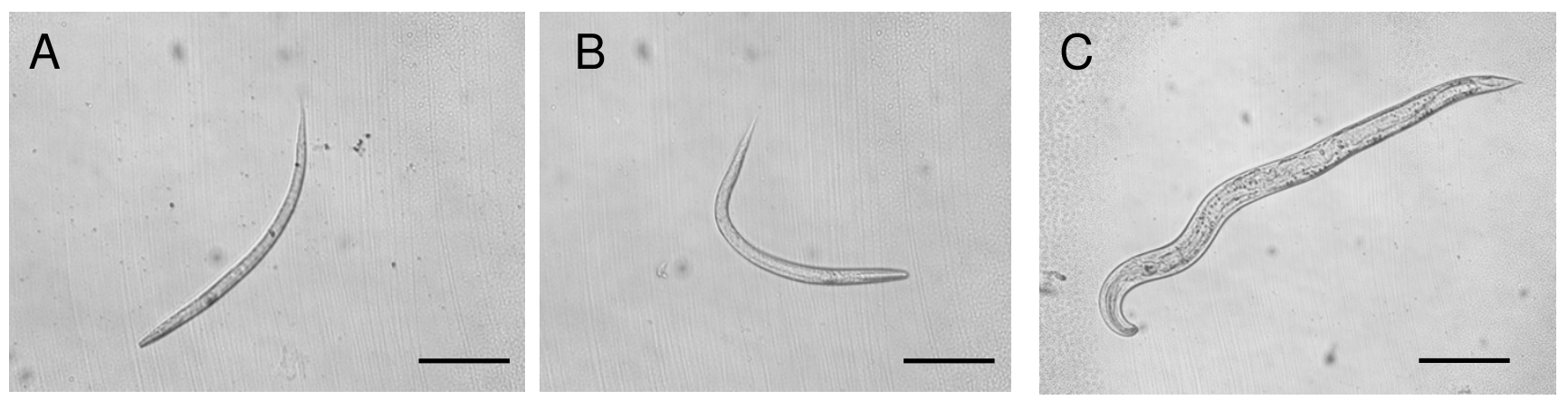

Figure 5

Larval arrest phenotypes obtained by plating $P$. superbus eggs onto agar plates containing a lawn of $E$. coli expressing dsRNA for $\boldsymbol{P}$. superbus genes encoding contractile proteins. (A) dsRNAi phenotype for Psu-ifb- $I$ (cytoplasmic intermediate filament protein) and (B) dsRNAi phenotype for Psu-act-2 (actin-2). These images were taken 9 days post hatching. By this time the control embryos which had been plated onto agar plates containing a lawn of $E$. coli containing the empty L4440 plasmid vector had reached adulthood (C). The scale bar represents $100 \mu \mathrm{M}$.

We have previously shown that Panagrolaimus is a suitable model for studies on the molecular basis of anhydrobiosis [57]. Panagrolaimid nematodes occupy a diversity of niches ranging from polar, temperate and semi-arid soils to terrestrial mosses. Thus many Panagrolaimus species are adapted to tolerate freezing and desiccation [81-83]. Our current data show that when fed on E. coli expressing dsRNA targeting Panagrolaimus genes the nematode mounts a potent and specific systemic RNAi response. This makes Panagrolaimus an ideal system with which to carry out high-throughput RNAi screens for studies on the molecular basis of anhydrobiosis and cryobiosis. Panagrolaimus is a member of the suborder Tylenchina of the Order Rhabditida and thus it is more distantly related to C. elegans than Oeschius or Pristionchus (Figure 6). The Suborder Tylenchina contains three major lineages [84]: the Panagrolaimorpha which includes the free living bacterial feeding panagrolaimids as well as the zooparasitic strongyloids and steinernematids; the Cephalobomorpha, bacterial feeding nematodes that, like the panagrolaimaids, have a widespread distribution and are capable of surviving in extremely dry and cold environments and the Tylenchomorpha, a group of plant parasites and fungal feeders which frequently has anhydrobiotic encysted infective stages (e.g. Globodera, Meliodogyne), as well as species which can enter anhydrobiosis throughout most or all of their life cycle (e.g. Aphelencus avenae). Within the genus Panagrolaimus several changes in reproductive mode have occurred. Examples of gonochoristic (male female), hermaphroditic (self-fertilization), and parthenogenetic (development of unfertilized eggs) reproduction have been reported [85]. Thus Panagrolaimus is an excellent model system to study the evolutionary origins and developmental consequences of parthenogenetic reproduction. Being closely related to the zooparasitic strongyloids and steinernematids and the plant parasitic tylenchid nematodes, Panagrolaimus could also be used in comparative genomic approaches to study the evolution of parasitic lifestyles.

\section{Conclusion}

Our results show that potent and specific RNAi effects can be achieved in two species of Panagrolaimus by feeding them on E. coli expressing dsRNA for genes with essential conserved functions. RNAi was first described in the nematode C. elegans, however some nematode species are refractory to RNAi, including O. tipulae $[37,38], P$. pacificus [39], several species of Caenorhabdtis [34,41] and some animal parasitic nematodes such as $H$. contortus [45] and O. ostertagi [46]. In contrast many species of plant parasitic nematodes have potent RNAi responses to exogenous RNAi $[48,49]$. Here we show that two species of Panagrolaimus are amenable to RNAi by feeding. Panagrolaimus is a soil dwelling bacterial feeding nematode, as are C. elegans, P. pacificus and O. tipulae, but as a member of the suborder Tylenchina Pangarolaimus is more distantly related to C. elegans than Oeschius or Pristionchus. Thus our data identify another nematode infraorder which is amenable to RNAi and provide additional information on the diversity of RNAi phenotypes in nematodes.

Panagrolaimaid nematodes occupy a diversity of niches ranging from polar, temperate and semi-arid soils to terrestrial mosses. Thus many Panagrolaimus species are adapted to tolerate freezing and desiccation [57,81-83]. Within the genus Panagrolaimus several changes in reproductive mode have occurred. Thus Panagrolaimus is an excellent model system to study the evolutionary origins and developmental consequences of parthenogenetic reproduction. Our demonstration that Panagrolaimus is amenable to RNAi by feeding will allow the development of high throughput methods of RNAi screening for $P$. 


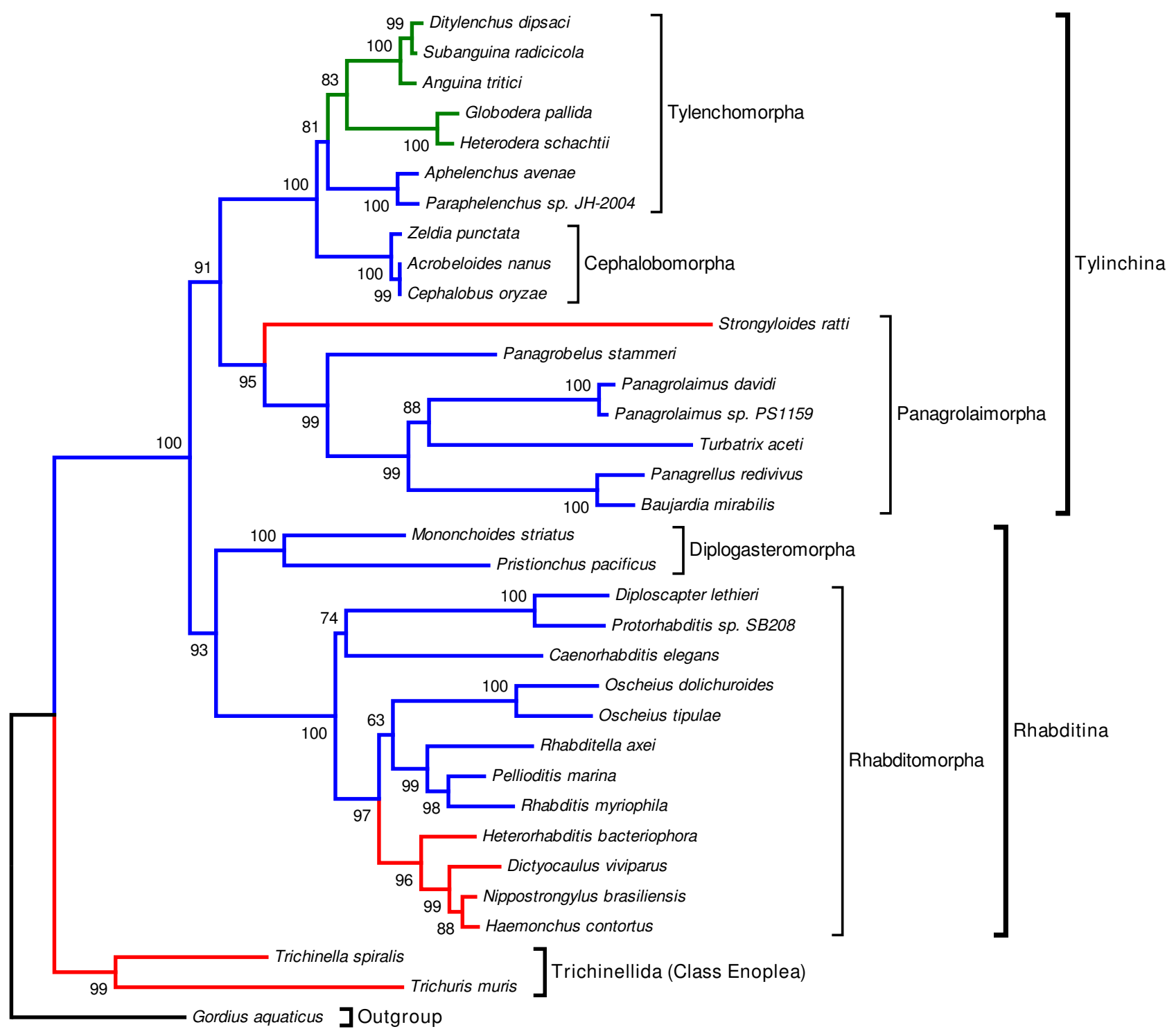

0.02 Nucleotide substitutions

Figure 6

The molecular phylogeny of selected members of the Order Rhabditida showing the phylogenetic relationships between Caenorhabditis elegans and other rhabditid and tylenchid nematodes. Lineages in blue correspond to free-living nematodes, plant parasite lineages are green and animal parasite lineages are red. This Minimum Evolution tree [92] was constructed using $18 \mathrm{~S}$ small subunit rRNA gene sequences. Bootstrap values (10,000 replicates) are placed next to the nodes.

superbus. This greatly enhances the utility of this nematode as a model system for the study of the molecular biology of anhydrobiosis and cryobiosis and as a possible satellite model nematode for comparative and functional genomics.
Methods

Source and culturing of Panagrolaimus sp. and Caenorhabditis elegans

The nematode strains C. elegans N2, and Panagrolaimus sp. PS1159 were obtained from the Caenorhabditis Genetics Centre (CGC). P. superbus (strain DF5050) was obtained from Prof. Bjorn Sohlenius, Swedish Museum of Natural 
History, Stockholm. The nematodes were cultured on NGM agar plates [57].

\section{E. coli feeding clones}

Two E. coli RNAi feeding clones from the C. elegans chromosome I feeding library [59] were kindly provided by Dr. Julie Ahringer, Department of Genetics, University of Cambridge. These clones contained inserts from the embryonic lethal genes Ce-ran-4 (R05D11.3) and Ce-lmn1 (DY3.2). Bacterial feeding strains were constructed for the Panagrolaimus genes using the L4440 plasmid vector [4] and Escherichia coli HT115(DE3) cells as described by Kamath and Ahringer [5]. The Panagrolaimus genes were selected from a panel of expressed sequence tags (ESTs) which we have generated for $P$. superbus and Panagrolaimus sp. PS1159 (Tyson et al. unpublished). The target genes were selected based on their gene identity as determined by BLAST analysis [86] and the RNAi phenotypes of their orthologs in C. elegans, as listed in WormBase [87]. The accession numbers of the Panagrolaimus ESTs and their cDNA fragment sizes are as follows: ef1b, EU368942 (625 bp); rps-2, EU368941 (649 bp); ifb-1, EU368943 (360 bp) and act-2, EU368944 (391 bp). Gene fragments of the ef $1 b$ and $r p s-2$ genes for insertion into the L4440 plasmid were prepared by PCR using the gene specific primer pairs EF1 Forward/EF1 Reverse and RPS Forward/RPS Reverse (The sequences of these PCR primers are listed in Additional File 1). Gene fragments corresponding to the entire EST sequences of the ifb-1 and act-2 genes were prepared from the plasmid name using M13 F and R primers and cloned into the L4440 vector. A separate control experiment (data not presented) showed that an RNAi feeding clone containing dsRNA for the multiple cloning site of the pDNRLIB plasmid had no observable phenotype when fed to $P$. superbus or Panagrolaimus sp. PS1159.

\section{RNAi feeding protocol}

NGM agar plates $(9 \mathrm{~cm})$ containing $1 \mathrm{mM}$ iso-propyl- $\beta$-Dthiogalactopyranoside (IPTG), $50 \mathrm{ug} / \mathrm{ml}$ ampicillin (Amp) and $12.5 \mathrm{ug} / \mathrm{ml}$ tetracycline (Tet) were prepared. The plates were allowed to dry inverted for $\sim 4$ days at room temperature. They were then were spread with cells from an overnight $E$. coli culture (strain HTT1(DE3)) containing the empty L4440 plasmid (control) or with E. coli HTT1(DE3) transformed with an L4440 plasmid containing the target gene fragment inserted into the multiple cloning site, and flanked on both sides by an IPTG-inducible T7 RNA polymerase promoter [4]. The plates were grown at $20^{\circ} \mathrm{C}$ overnight to allow a lawn of E. coli to form and to begin induction and expression of dsRNA. Axenised eggs were prepared from gravid female nematodes by bleaching them with hypochlorite [88]. The axenised eggs were rinsed three times in S Basal buffer [58], then aliquotted onto NGM agar feeding plates. The plates were incubated at $20^{\circ} \mathrm{C}$ and monitored daily for the presence of visible RNAi phenotypes in the treated nematodes. To analyse embryonic lethal RNAi phenotypes young L4 stage worms were rinsed from the treatment and control plates using sterile S Basal buffer and approximately 5 worms were transferred to each of 5-8 replicate $3 \mathrm{~cm}$ NGM/IPTG/Amp/Tet agar plates containing a lawn of either control E. coli or E. coli expressing dsRNA for the target gene. These worms were allowed to grow to adulthood and lay eggs for 24 hours and they were then transferred to a second set of replicate plates. The worms were again allowed to lay eggs for 24 hours before being transferred to a third set of plates. The worms were allowed to lay eggs on the third set of plates until laying ceased and the adult worms were then removed from the plates. The number of dead embryos on each of the three sets of plates was determined by microscopic observation over a number of days for both the control and experimental treatments. Standard deviation and standard errors were calculated using the individual counts of surviving nematodes and not on proportional data, but in the histograms survival data are presented as percentage survival.

To observe possible embryonic lethal RNAi phenotypes synchronous eggs from control and RNAi treated cultures were rinsed from the agar surface using $S$ Basal buffer and centrifuged at 3,000 $\mathrm{g}$ for five minutes. The concentrated eggs were transferred to a glass slide and gently covered with a glass cover slip. Embryos were observed using an Olympus EX51 microscope fitted with a U-CMAD3 imaging system and an Olympus U-RFL-T camera.

\section{$R T-P C R$ analysis of gene expression levels}

Individual adult female nematodes whose progeny displayed an embryonic lethal RNAi phenotype were used for RT-PCR. RNA was isolated from single nematodes using the Absolutely RNA Microprep Kit (Stratagene), which also included a DNAse treatment prior to the reverse transcription step to remove any genomic DNA (gDNA) contamination. As a control, PCR was attempted on each sample after DNAse treatment and prior to RTPCR to ensure all gDNA had been removed. PCR samples were then analysed by spectrophotometry and agarose gel electrophoresis and samples showing no gDNA amplification were chosen for RT-PCR experiments. Each worm RNA preparation yielded $30 \mu \mathrm{l}$ of extracted RNA. Six $\mu \mathrm{l}$ of the extracted RNA solution was used for each RT-PCR reaction. RT-PCR was carried out using the QuanTitect SYBR Green RT-PCR kit (Qiagen). The upstream test forward primers used for RT-PCR analysis targeted a region not included in the dsRNA feeding construct. The primers used were the EF1-F-TEST and the EF1 reverse primers for the ef $1 b$ gene and the RPS-F-TEST and the RPS reverse primers for the rps-2 gene. The sequences of all PCR primers are listed in Additional File 1. RT-PCR was also carried using the D3 expansion region of the ribosomal RNA gene 
as an internal control gene for each single worm RNA preparation. Amplification of the rRNA D3 domain was carried out as described previously [57]. The RT-PCR conditions were as follows: $94^{\circ} \mathrm{C}$ for $5 \mathrm{~min}$ at the start of the reaction was followed by 30 minutes at $50^{\circ} \mathrm{C}$ to allow reverse transcription of the RNA. The PCR cycling conditions were as follows: $94^{\circ} \mathrm{C}, 1 \mathrm{~min} ; 55^{\circ} \mathrm{C}, 1.5 \mathrm{~min} ; 72^{\circ} \mathrm{C}$, 2 min. To obtain PCR product during the linear phase of the PCR reaction a $10 \mu \mathrm{l}$ aliquot from the PCR reaction mixture was sampled at 20, 25, 30 and 35 cycles for each gene used. The products of the RT-PCR reactions were visualised on $1 \%$ agarose gels with $10 \mu \mathrm{l}$ of each RT-PCR product loaded per gel. Image analysis of the RT-PCR gels was carried out and band intensities were measured in machine units using the ImageQuant ${ }^{\mathrm{TM}} \mathrm{TL}$ software package from GE Healthcare.

\section{Phylogenetic analyses}

Nucleotide sequences for the $18 \mathrm{~S}$ small subunit rRNA nuclear gene of 34 taxa were downloaded from the NCBI database [89]. The accession numbers for these sequences are given in Additional File 2. The sequences were aligned using the ClustalW algorithm as implemented in the MEGA software package (version 3.1) [90]. The alignment was manually edited by removing poorly aligned blocks at the $5^{\prime}$ and $3^{\prime}$ ends and ambiguously aligned internal segments. The final alignment contained 1,275 aligned characters. Phylogenetic trees were constructed using the Neighbor-Joining method [91] and Minimum Evolution method [92] as implemented by MEGA version 3.1. The tree topologies recovered trees by both methods were very similar, differing only in the placement of the Oscheius clade (see Figure 6 and Additional File 3 ).

\section{Statistical analyses}

All statistical analyses were carried out using Minitab ${ }^{\text {тм }}$ version 14.1 (Minitab Inc., State College, Pennsylvania, USA). The 2-tailed T-Test was used to test for difference between populations. The null hypothesis that population means are all equal was tested at the $P=0.05$ level of significance. T-Tests were carried out using the individual counts of surviving nematodes and not on proportional data.

\section{Authors' contributions}

AJS and TT did the RNAi experiments. ID selected and tested the C. elegans feeding constructs. ID and AJS carried out the microscopy. AJS did the RT-PCR experiments. JB selected and prepared the Panagrolaimus sp. PS1159 cDNA sequences. $\mathrm{AMB}$ did the phylogenetic reconstruction. $\mathrm{AMB}, \mathrm{AJS}$, TT and ID designed the study and AMB coordinated the study. AJS and AMB drafted the manuscript. All authors read and approved the final manuscript.

\section{Additional material}

\section{Additional file 1}

Table 1. Sequences of the PCR primers used for single nematode RT-PCR. Click here for file

[http://www.biomedcentral.com/content/supplementary/1471-

2199-9-58-S1.doc]

\section{Additional file 2}

Table 2. Accession Numbers of the small subunit ribosomal RNA sequences used to construct a molecular phylogeny of selected members of the Order Rhabditida.

Click here for file

[http://www.biomedcentral.com/content/supplementary/1471-

2199-9-58-S2.doc]

\section{Additional file 3}

Additional figure. The molecular phylogeny of selected members of the Order Rhabditida showing the phylogenetic relationships between Caenorhabditis elegans and other rhabditid and tylenchid nematodes. Lineages in blue correspond to free-living nematodes, plant parasite lineages are green and animal parasite lineages are red. This Neighbor-Joining tree [91] was constructed using $18 S$ small subunit rRNA gene sequences. Bootstrap values $(10,000$ replicates $)$ are placed next to the nodes.

Click here for file

[http://www.biomedcentral.com/content/supplementary/14712199-9-58-S3.doc]

\section{Acknowledgements}

This work was funded by a Science Foundation Ireland Investigator Programme Grant and by the Leverhulme Trust. We thank Dr. Julie Ahringer who kindly sent us the Caenorhabditis elegans feeding strains for the Ce-ran4 and Ce-Imn-I genes.

\section{References}

I. Fire A, Xu S, Montgomery MK, Kostas SA, Driver SE, Mello CC: Potent and specific genetic interference by double-stranded RNA in Caenorhabditis elegans. Nature 1998, 391:806-8I I.

2. Montgomery MK, Xu SQ, Fire A: RNA as a target of doublestranded RNA-mediated genetic interference in Caenorhabditis elegans. Proc Natl Acad Sci USA 1998, 95:15502-I5507.

3. Tabara H, Grishok A, Mello CC: RNAi in C. elegans: Soaking in the genome sequence. Science 1998, 282:430-43I.

4. Timmons L, Fire A: Specific interference by ingested dsRNA. Nature 1998, 395:854-854.

5. Kamath RS, Ahringer J: Genome-wide RNAi screening in Caenorhabditis elegans. Methods 2003, 30:313-32I.

6. Zipperlen P, Fraser AG, Kamath RS, Martinez-Campos M, Ahringer ]: Roles for 147 embryonic lethal genes on $C$. elegans chromosome I identified by RNA interference and video microscopy. EMBO J 200 I, 20( I 5):3984-3992.

7. Labbe JC, Pacquelet A, Marty T, M G: A genome wide screen for suppressors of par-2 uncovers potential regulators of PAR protein-dependent cell polarity in Caenorhabditis elegans. Genetics 2006, I 74:285-295.

8. Murphy CT, McCarroll SA, Bargmann Cl, Fraser A, Kamath RS, Ahringer J, Li H, Kenyon C: Genes that act downstream of DAF16 to influence the lifespan of Caenorhabditis elegans. Nature 2003, 424:277-284.

9. Hamilton B, Dong Y, Shindo M, Liu W, Odell I, Ruvkun G, Lee SS: A systematic RNAi screen for longevity genes in C. elegans. Genes Dev 2005, 19:1544-1555. 
10. Curran SP, Ruvkun G: Lifespan regulation by evolutionarily conserved genes essential for viability. PloS Genet 2007, 3(4):e56.

II. Lettre G, Kritikou EA, Jaeggi M, Calixto A, Fraser AG, Kamath RS Ahringer J, Hengartner MO: Genome-wide RNAi identifies p53dependent and -independent regulators of germ cell apoptosis in C. elegans. Cell Death Differ 2004, I I: I I 98- I 203.

12. Golden A, O'Connell KF: Silence is golden: combining RNAi and live cell imaging to study cell cycle regulatory genes during Caenorhabditis elegans development. Methods 2007, 41:190-197.

13. Schmitz $\mathrm{C}$, Kinge $\mathrm{P}$, Hutter $\mathrm{H}$ : Axon guidance genes identified in a large-scale RNAi screen using the RNAi-hypersensitive Caenorhabditis elegans strain nre-I(hd20) lin-I5b(hdI26). Proc Natl Acad Sci USA 2007, 1 04:834-839.

14. Cerutti $\mathrm{H}$, Casas-Mollano JA: On the origin and functions of RNA-mediated silencing: from protists to man. Curr Genet 2006, 50:81-99.

15. Bernstein E, Caudy AA, Hammond SM, Hannon GJ: Role for a bidentate ribonuclease in the initiation step of RNA interference. Nature 200I, 409:363-366.

16. Hammond SM, Hammond EB, Beach D, Hannon GJ: An RNAdirected nuclease mediates post-transcriptional gene silencing in Drosophila cells. Nature 2000, 404:293-296.

17. Nykanen A, Haley B, Zamore PD: ATP requirements and small interfering RNA structure in the RNA interference pathway. Cell 200I, I 07:309-32I.

18. Pasquinelli AE, Reinhart BJ, Slack F, Martindale MQ, Kuroda MI, Maller B, Hayward DC, Ball EE, Degnan B, Muller P, Spring J, Srinivasan A, Fishman M, Finnerty J, Corbo J, Levine M, Leahy P, Davidson E, Ruvkun G: Conservation of the sequence and temporal expression of let-7 heterochronic regulatory RNA. Nature 2000, 408:86-89.

19. Jones-Rhoades MW, Bartel DP, Bartel B: MicroRNAs and their regulatory roles in plants. Ann Rev Plant Biol 2006, 57:19-53.

20. Volpe TA, Kidner C, Hall IM, Teng G, Grewal SIS, Martienssen RA: Regulation of heterochromatic silencing and histone $\mathbf{H 3}$ lysine-9 methylation by RNAi. Science 2002, 297: 1833-1837.

21. Wassenegger M: The role of the RNAi machinery in heterochromatin formation. Cell 2005, I22:13-16.

22. Clemens JC, Worby CA, Simonson-Leff N, Muda M, Maehama T, Hemmings BA, Dixon JE: Use of double-stranded RNA interference in Drosophila cell lines to dissect signal transduction pathways. Proc Natl Acad Sci USA 2000, 97:6499-6503.

23. Roignant JY, Carre C, Mugat $R$, Szymczak D, Lepesant JA, Antoniewski C: Absence of transitive and systemic pathways allows cell-specific and isoform-specific RNAi in Drosophila. RNA 2003, 9:299-308.

24. Ciche TA, Sternberg PW: Postembryonic RNAi in Heterorhabditis bacteriophora: a nematode insect parasite and host for insect pathogenic symbionts. BMC Dev Biol 2007, 7:101.

25. Alvarado AS, Newmark PA: Double-stranded RNA specifically disrupts gene expression during planarian regeneration. Proc Natl Acad Sci USA 1999, 96:5049-5054.

26. Lohmann JU, Endl I, Bosch TCG: Silencing of developmental genes in Hydra. Dev Biol 1999, 2 | 4:2 I|-2।4.

27. Dong Y, Friedrich M: Nymphal RNAi: systemic RNAi mediated gene knockdown in juvenile grasshopper. BMC Biotech 2005, 5:25.

28. Ciudad L, Piulachs MD, Belles X: Systemic RNAi of the cockroach vitellogenin receptor results in a phenotype similar to that of the Drosophila yolkless mutant. FEBS J 2006, 273:325-335.

29. Klahre U, Crete P, Leuenberger SA, Iglesias VA, Meins F: High molecular weight RNAs and small interfering RNAs induce systemic posttranscriptional gene silencing in plants. Proc Natl Acad Sci USA 2002, 99: I 1981-II 986.

30. Bezanilla M, Pan A, Quatrano RS: RNA interference in the moss Physcomitrella patens. Plant Physiol 2003, I33:470-474.

31. Voinnet O: Non-cell autonomous RNA silencing. FEBS Lett 2005, 579:5858-587l.

32. Small I: RNAi for revealing and engineering plant gene functions. Curr Opin Biotechnol 2007, I 8: I48-153.

33. Winston WM, Molodowitch C, Hunter CP: Systemic RNAi in C. elegans requires the putative transmembrane protein SID-I. Science 2002, 295:2456-2459.
34. Winston WM, Sutherlin $M$, Wright $A J$, Feinberg $E H$, Hunter CP: Caenorhabditis elegans SID-2 is required for environmental RNA interference. Proc Natl Acad Sci USA 2007, I 04: I 0565-I 0570.

35. Feinberg EH, Hunter CP: Transport of dsRNA into cells by the transmembrane protein SID- I. Science 2003, 30 I : I 545-I547.

36. DaRocha WD, Otsu K, Teixeira SMR, Donelson JE: Tests of cytoplasmic RNA interference (RNAi) and construction of a tetracycline-inducible T7 promoter system in Trypanosoma cruzi. Mol Biochem Parasitol 2004, I33:175-I86.

37. Louvet-Vallée S, Kolotuev I, Podbilewicz B, Felix MA: Control of vulval competence and centering in the nematode Oscheius sp. I CEWI. Genetics 2003, 163:133

38. Félix MA: Oscheius tipulae. WormBook 2006 [http://www.worm book.org]

39. Pires-DaSilva A, Sommer RJ: Conservation of the global sex determination gene tra- $I$ in distantly related nematodes. Genes Dev 2004, I 8: I 198-1208.

40. Sommer RJ: Pristionchus pacificus. WormBook 2006 [http:// www.wormbook.org].

4I. Descotte V, Montgomery MK: Differing susceptibilities to RNAi within the Caenorhabditis clade. Dev Biol 2003, 259:466.

42. Tijsterman M, Okihara KL, Thijssen K, Plasterk RHA: PPW-I, a PAZIPIWI protein required for efficient germline RNAi, is defective in a natural isolate of C. elegans. Curr Biol 2002, I 2( I 7): I535-1540.

43. Tolia NH, Joshua-Tor L: Slicer and the Argonautes. Nat Chem Biol 2007, 3:36-43.

44. Parker JS, Barford D: Argonaute: a scaffold for the function of short regulatory RNAs. Trends Biochem Sci 2006, 3 I :622-630.

45. Geldhof P, Murray L, Couthier A., Gilleard J, McLauchlan G, Knox D, Britton C: Testing the efficacy of RNA interference in Haemonchus contortus. Int J Parasitol 2006, 36:80I-8I0.

46. Visser A, Geldhof P, De Maere V, Knox DP, Vercruysse J, Claerebout $E$ : Efficacy and specificity of RNA interference in larval lifestages of Ostertagia ostertagi. Parasitology 2006, I 33:777-783.

47. Knox DP, Geldhof $P$, Visser A, Britton C: RNA interference in parasitic nematodes of animals: a reality check? Trends Parasitol 2007, 23:105-107.

48. Urwin PE, Lilley CJ, Atkinson HJ: Ingestion of double-stranded RNA by preparasitic juvenile cyst nematodes leads to RNA interference. Mol Plant Microbe Interact 2002, I 5:747-752.

49. Bakhetia M, Charlton W, Atkinson HJ, McPherson M: RNA interference of dual oxidase in the plant nematode Meloidogyne incognita. Mol Plant Microbe Interact 2005, I 8( I 099-I I 06):

50. Viney ME, Thompson FJ: Two hypotheses to explain why RNA interference does not work in animal parasitic nematodes. Int J Parasitol 2008, 38:43-47.

5I. Worby CA, Simonson-Leff N, Dixon JE: RNA interference of gene expression (RNAi) in cultured Drosophila cells. SCi STKE 200I, 200I(95):pll.

52. Saleh MC, van Rij RP, Hekele A, Gillis A, Foley E, O'Farrell PH, Andino $\mathrm{R}$ : The endocytic pathway mediates cell entry of dsRNA to induce RNAi silencing. Nat Cell Biol 2006, 8(8):793-802.

53. Plasterk RHA: RNA silencing: The genome's immune system. Science 2002, 296: I 263-1265

54. Buchon N, Vaury C: RNAi: a defensive RNA-silencing against viruses and transposable elements. Heredity 2006, 96: I 95-202.

55. Li F, Ding SW: Virus counterdefense: Diverse strategies for evading the RNA-silencing immunity. Annu Rev Microbiol 2006, 60:503-531.

56. Peiser L, Mukhopadhyay S, Gordon S: Scavenger receptors in innate immunity. Curr Opin Immunol 2002, I 4: I 23-I 28.

57. Shannon AJ, Browne JA, Boyd J, Fitzpatrick DA, Burnell AM: The anhydrobiotic potential and molecular phylogenetics of species and strains of Panagrolaimus (Nematoda, Panagrolaimidae). J Exp Biol 2005, 208:2433-2445.

58. Brenner S: The genetics of Caenorhabditis elegans. Genetics 1974, 77:7|-94.

59. Fraser AG KRS Zipperlen P, Martinez-Campos M, Sohrmann M, Ahringer J,: Functional genomic analysis of $C$. elegans chromosome I by systematic RNA interference. Nature 2000, 408:325-330.

60. Liu J, Ben-Shahar TR, Riemer D, Treinin M, Spann P, Weber K, Fire A, $Y$. G: Essential roles for Caenorhabditis elegans lamin gene in nuclear organization, cell cycle progression, and spatial 
organization of nuclear pore complexes. Mol Biol Cell 2000 , I I:3937-3947.

61. Quimby BB, Lamitina T, L'Hernault SW, Corbett AH: The mechanism of Ran import into the nucleus by nuclear transport factor 2. J Biol Chem 2000, $275: 28575-28582$.

62. Ribbeck K, Lipowsky G, Kent HM, Stewart M, Gorlich D: NTF2 mediates nuclear import of Ran. EMBO J 1998, 17:6587-6598.

63. Gorlich $D$ : Transport into and out of the cell nucleus. $E M B O J$ 1998, $17: 2721-2727$

64. Kamath RS, Fraser AG, Dong Y, Poulin G, Durbin R, Gotta M, Kanapin A, Le Bot N, Moreno S, Sohrmann M, Welchman DP, Zipperlen $P$, Ahringer I: Systematic functional analysis of the Caenorhabditis elegans genome using RNAi. Nature 2003, 42 I:23I-237.

65. Simmer F, Tijsterman M, Parrish S, Koushika SP, Nonet ML, Fire A, Ahringer J, Plasterk RHA: Loss of the putative RNA-directed RNA polymerase RRF-3 makes $C$. elegans hypersensitive to RNAi. Curr Biol 2002, I2:1317-1319.

66. Francis R, Waterston RH: Muscle cell attachment in Caenorhabditis elegans. J Cell Biol I99I, I I 4:465-479.

67. Woo WM, Goncharov A, Jin Y, Chisholm AD: Intermediate filaments are required for $C$. elegans epidermal elongation. Dev Biol 2004, 267:216-229.

68. Karabinos A, Schulze E, Schünemann J, Parry DAD, Weber K: In vivo and in vitro evidence that the four essential intermediate filament (IF) proteins AI, A2, A3 and BI of the nematode Caenorhabditis elegans form an obligate heteropolymeric IF system. J Mol Biol 2003, 333:307-319.

69. Waterston RH, Hirsh D, Lane TR: Dominant mutations affecting muscle structure in Caenorhabditis elegans that map near the actin gene-cluster. J Mol Biol 1984, 180:473-496.

70. Stone S, Shaw JE: A Caenorhabditis elegans act-4:lacZ fusion used as a transformation marker and analysis of tissue-specific expression. Gene 1993, 131:167-173.

7I. MacQueen AJ, Baggett J], Perumov N, Bauer RA, Januszewski T, Schriefer L, Waddle JA: ACT-5 is an essential Caenorhabditis elegans actin required for intestinal microvilli formation. Mol Biol Cell 2005, 16:3247-3259.

72. Willis JH, Munro E, Lyczak R, Bowerman B: Conditional dominant mutations in the Caenorhabditis elegans gene act-2 identify cytoplasmic and muscle roles for a redundant actin. Mol Biol Cell 2006, 17:105I-1064.

73. Landel CP, Krause M, Waterston RH, D. H: DNA rearrangements of the actin gene-cluster in Caenorhabditis elegans accompany reversion of three muscle mutants. J Mol Biol 1984, | 80:497-5 I3.

74. Avery L: The genetics of feeding in Caenorhabditis elegans. Genetics 1993, 133:897-917.

75. Meldal BH, Debenham NJ, De Ley P, De Ley IT, Vanfleteren JR, Vierstraete AR, Bert W, Borgonie G, Moens T, Tyler PA, Austen MC, Blaxter ML, Rogers AD, Lambshead PJ: An improved molecular phylogeny of the Nematoda with special emphasis on marine taxa. Mol Phylo Evol 2006, 42:622-636.

76. Stein LD, Bao ZR, Blasiar D, Blumenthal T, Brent MR, Chen NS, Chinwalla A, Clarke L, Clee C, Coghlan A, Coulson A, D'Eustachio P, Fitch DH, Fulton LA, Fulton RE, Griffiths-Jones S, Harris TW, Hillier LW, Kamath R, Kuwabara PE, Mardis ER, Marra MA, Miner TL, Minx P, Mullikin JC, Plumb RW, Rogers J, Schein JE, Sohrmann M, Spieth J, Stajich JE, We CC, Willey D, Wilson RK, Durbin R, Waterston RH: The genome sequence of Caenorhabditis briggsae: A platform for comparative genomics. PloS Biol 2003, I (2): E45.

77. Félix MA: Cryptic quantitative evolution of the vulva intercellular signaling network in Caenorhabditis. Curr Biol 2007 17:103-114.

78. Félix MA, Delattre M, Dichtel ML: Comparative developmental studies using Oscheius/Dolichorhabditis sp. CEWI (Rhabditidae). Nematology 2000, 2:88-89.

79. Hong RL, Sommer RJ: Pristionchus pacificus: a well-rounded nematode. Bioessays 2006, 28:65I-659.

80. Heasman J: Morpholino oligos: making sense of antisense? Dev Biol 2002, 243:209-2।4.

81. Ricci C, Pagani M: Desiccation of Panagrolaimus rigidus (Nematoda): survival, reproduction and the influence on the internal clock. Hydrobiologia 1997, 347: I- I3.

82. Aroian RV, Carta L, Kaloshian I, Sternberg PW: A free-living Panagrolaimus sp from Armenia can survive in anhydrobiosis for 8.7 years. J Nematol 1993, 25:500-502.
83. Wharton DA, Goodall G, Marshall C): Freezing survival and cryoprotective dehydration as cold tolerance mechanisms in the Antarctic nematode Panagrolaimus davidi. J Exp Biol 2003, 206:215-22I.

84. De Ley P, Blaxter ML: Systematic position and phylogeny. In The Biology of Nematodes Edited by: Lee D. Harwood Academic Publishers; $2002: 1-30$

85. Félix MA, De Ley P, Sommer RJ, Frisse L, Nadler SA, Thomas WK, Vanfleteren J, Sternberg PW: Evolution of vulva development in the Cephalobina (Nematoda). Dev Biol 2000, 221 :68-86.

86. Blast Home [http://www.ncbi.nlm.nih.gov/BLAST/]

87. Wormbase [http://www.ncbi.nlm.nih.gov/]

88. Lewis JA, Fleming JT: Basic Culture Methods. In Caenorhabditis elegans: Modern Biological Analysis of an Organism Volume 48. Edited by: Epstein HF, Shakes DC. Methods in Cell Biology; 1995:3-29.

89. National Center for Biotechnology Information [http://
] www.ncbi.nlm.nih.gov/]

90. Kumar S, Tamura K, Nei M: MEGA3: Integrated software for Molecular Evolutionary Genetics Analysis and sequence alignment. Brief Bioinform 2004, 5(): 150-163.

9l. Saitou N, Nei M: The Neighbor-Joining method - a mew method for reconstructing phylogenetic trees. Mol Biol Evol 1987, 4:406-425.

92. Rzhetsky A, Nei M: A simple method for estimating and testing minimum-evolution trees. Mol Biol Evol 1992, 9:945-967 [http:// mbe.oxfordjournals.org/cgi/reprint/9/5/945.pdf].
Publish with Biomed Central and every scientist can read your work free of charge

"BioMed Central will be the most significant development for disseminating the results of biomedical research in our lifetime. "

Sir Paul Nurse, Cancer Research UK

Your research papers will be:

- available free of charge to the entire biomedical community

- peer reviewed and published immediately upon acceptance

- cited in PubMed and archived on PubMed Central

- yours - you keep the copyright

Submit your manuscript here:

http://www.biomedcentral.com/info/publishing_adv.asp
BioMedcentral 